\title{
Bands of Zircon, Allanite and Magnetite in Paleozoic Alkali Granite in the Chungju Unit, South Korea, and Origin of REE Mineralizations
}

\author{
Sang-Gun No ${ }^{1, *}$ and Maeng-Eon Park ${ }^{2}$ \\ 1 Mineral Resources Research Division, Korea Institute of Geoscience and Mineral Resources, \\ Daejeon 34132, Korea \\ 2 Department of Earth and Environmental Science, Pukyong National University, Busan 48513, Korea; \\ mepark@pknu.ac.kr \\ * Correspondence: geologist@kigam.re.kr; Tel.: +82-10-9348-7807
}

Received: 28 August 2019; Accepted: 12 September 2019; Published: 19 September 2019

\begin{abstract}
High-grade $\mathrm{Zr}-\mathrm{Nb}-\mathrm{Y}$-rare earth element (REE) mineralization occurs as zircon-allanite-magnetite bands in layered Paleozoic alkali rocks which intruded the Gyemyeongsan Formation of the Chungju unit, South Korea. The mineralization period and genesis have been controversial. We investigated the petrological and mineralogical properties of the newly discovered zircon-allanite-magnetite bands and the geochronological properties of zircon within the bands in the alkali granite. We analyzed the zircon with laser ablation multi-collector inductively coupled plasma mass spectrometry (LA-MC-ICP-MS). The repeated quartz-feldspar-rich layers in the alkali granite show grain-sized grading textures and equilibrium igneous textures. Magnetite and allanite grains in these layers varied in size and exhibited isolated, aggregated, and coalesced textures. In addition, the settling texture of zircon grains onto the other minerals was observed. These observations could reasonably be explained by the process of gravitational accumulation during the solidification of magma. The ${ }^{206} \mathrm{~Pb} /{ }^{238} \mathrm{U}$ ages obtained from zircon from the zircon-allanite-magnetite-rich layer and the alkali aplite were $331.1 \pm 1.5 \mathrm{Ma}$ and $334.5 \pm 8.9 \mathrm{Ma}$, respectively. Therefore, we suggest that the $\mathrm{Zr}-\mathrm{Y}-\mathrm{Nb}-\mathrm{REE}$ mineralization developed in the alkali rocks and the Gyemyeongsan Formation in the Chungju unit were formed by fractional crystallization of alkali magma and hydrothermal fluids which evolved from alkali magma fractional crystallization, respectively. The correlation between alkaline granite and REE mineralization found in this study could be used as a tool for REE exploration in other regions where the permeable geological unit is intruded by the alkali granite.
\end{abstract}

Keywords: $\mathrm{Zr}-\mathrm{Nb}-\mathrm{Y}-\mathrm{REE}$ mineralization; zircon-allanite-magnetite band; layered alkali granite; fractional crystallization; coalescence; settling

\section{Introduction}

The Chungju deposit is located in the central part of the southern Korean Peninsula (Figure 1). The deposit contains especially high grades of zirconium $\left(\mathrm{ZrO}_{2}=9.6-25.3 \%\right)$, niobium $\left(\mathrm{Nb}_{2} \mathrm{O}_{5}=1.2-2.3 \%\right)$, yttrium $\left(\mathrm{Y}_{2} \mathrm{O}_{3}=0.5-1.5 \%\right.$ ), and total rare earth elements (REE; $\mathrm{REE}_{2} \mathrm{O}_{3}=1.07-2.7 \%$ ) [1,2]. This deposit is hosted in the Gyemyeongsan Formation [1-3], which belongs to the Chungju unit and is located in the northwestern region of the Okcheon Metamorphic Belt (Figure 1). The presence of REE mineralizations in the Chungju area, including geochemical data for some REE minerals, was first reported in 1989 [3]; this was followed by reports on the genesis of REE mineralizations [1,2]. In addition, the chemical compositions of the alkali granite [4] and REE-bearing minerals [5,6], and the associated uranium and thorium mineralization [7], have also been studied. Previous studies [1,2,4-7] that have been carried out in the present study area report mineralized zones that were developed by 
alkaline hydrothermal alteration (330 $\pm 20 \mathrm{Ma}$; [1]) derived from alkali granitic rocks (331 $\pm 20 \mathrm{Ma}$; [2]. However, the $\mathrm{Sm}-\mathrm{Nd}$ age of the whole rock is not widely accepted because of the wide error range of the analytical method. Recently, mineral chemistry of some REE minerals [8] from the Gyemyeongsan Formation in the Chungju REE deposit, as well as their ages of mineralization (allanite; $446 \pm 8.0$, 300-220, 199-183 Ma [9]), are reported. Studies were conducted on samples from Mt. Eorae, which is located approximately $6 \mathrm{~km}$ to the west of the study area $[3,8,9]$. The REE contained in alkali volcanic rocks, which were formed by the disruption of the supercontinent Rodinia, were concentrated by episodic tectonothermal events [9]. Here, we investigated the petrological and mineralogical properties of zircon-allanite-magnetite bands and the geochronological properties of zircon within the bands in alkali granite using multi-collector inductively coupled plasma mass spectrometry (ICP-MS). In a previous study, the zircon ages were not obtained because the grain size was too small to analyze. As a result, we suggested that the $\mathrm{Zr}-\mathrm{Nb}-\mathrm{Y}-\mathrm{REE}$ mineralization occurred within the alkali granite during the fractional crystallization of alkali magma in the Paleozoic period. Furthermore, alkali fluid derived from alkali magma mineralized the Gyemyeongsan Formation.

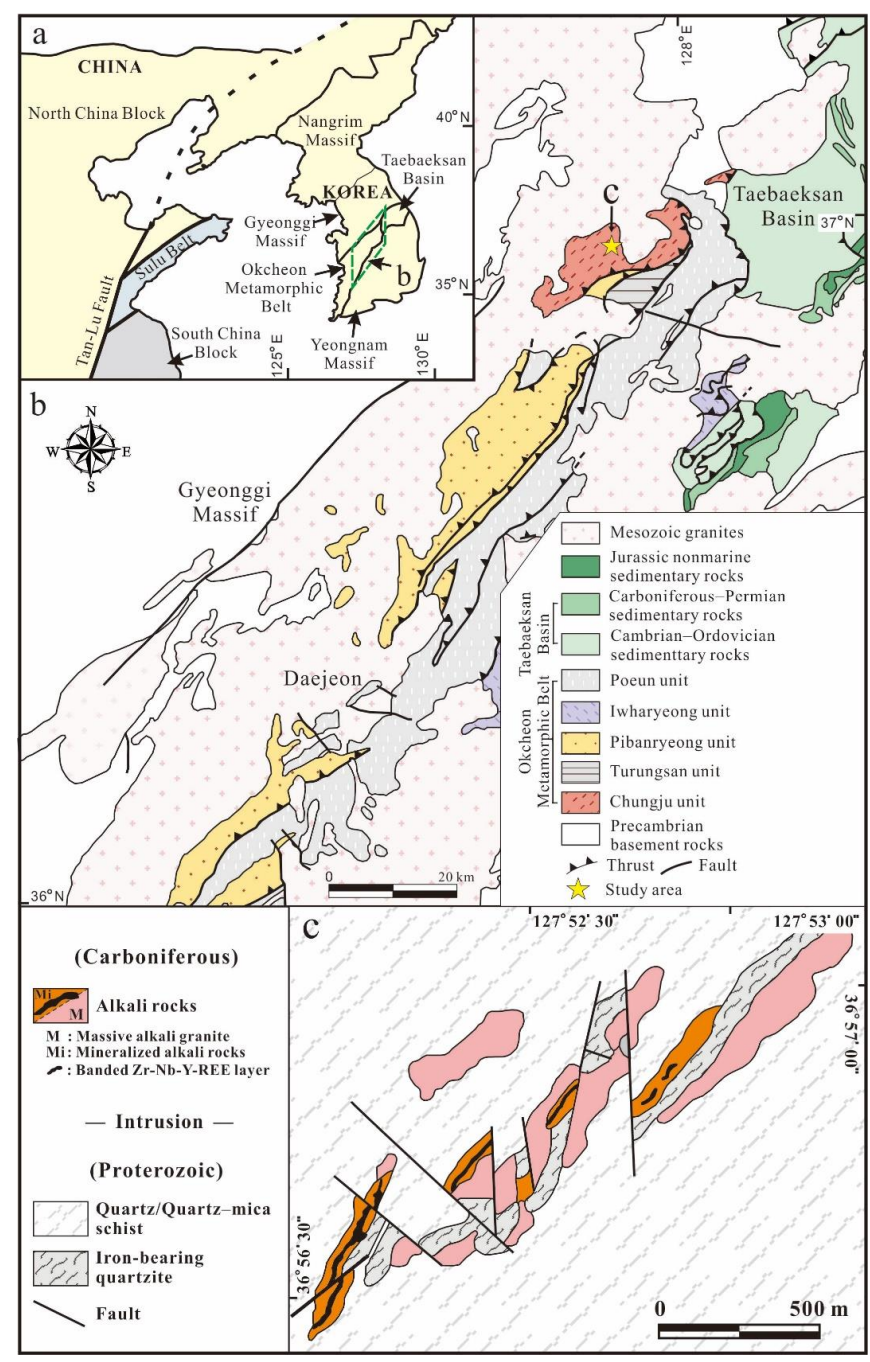

Figure 1. The location of the Chungju deposit and its geological setting. (a) A simplified map showing the tectonic provinces of East Asia, including the Korean Peninsula, modified from Reference [9]. (b) A geological map showing the stratigraphic/lithotectonic units of the Okcheon Metamorphic Belt and the Taebaeksan Basin, modified from Reference [9]. (c) A geological map of the studied area, modified from Reference [1]. 


\section{Geological Setting}

The Korean Peninsula comprises three major Precambrian massifs, namely, the Nangrim, Gyeonggi, and Yeongnam massifs (Figure 1). The Gyeonggi and Yeongnam massifs are separated by the Okcheon Belt that comprises the weakly metamorphosed Paleozoic Taebaeksan Basin and the Okcheon Metamorphic Belt (OMB). The OMB mainly consists of metasedimentary and metavolcanic sequences that range in metamorphic grade up to amphibolite facies conditions [10]. The OMB can be correlated with the suture zone between the Yangtze and Cathaysia blocks [11] because the suture zone in the South China Block was reactivated as a rift at $820-750$ Ma during the breakup of the supercontinent Rodinia [12], which caused rift-related bimodal volcanism (756 Ma) in the OMB [13]. The OMB has been interpreted to represent a stack of syn-metamorphic nappes [14,15] that comprise, from bottom to top, the Chungju, Turungsan, Pinbanryeong, Iwharyeong, and Poeun structural units (Figure 1). The alkali granite and $\mathrm{Zr}-\mathrm{Nb}-\mathrm{Y}-\mathrm{REE}$ mineralization are located within the Gyemyeongsan Formation in the Chungju unit (Figure 1), which is mainly composed of schistose rocks and iron-bearing quartzites [1]. The schistose rocks are the dominant rock type of the Gyemyeongsan Formation, and they are derived from lavas and tuffs [16]. The quartz-feldspar schist which is one of the schistose rocks contains substantial amounts of REE-bearing minerals, such as allanite, sphene, pyrochlore, and zircon [1]. The iron-bearing quartzite is commonly intercalated with schistose rocks. The granitic rocks that intruded into the Gyemyeongsan Formation occur as plutons, stocks, and dikes (Figure 1). These granitic rocks include Mesozoic biotite granite and hornblende granite, and the Paleozoic alkali granite (Figures 1c and 2).
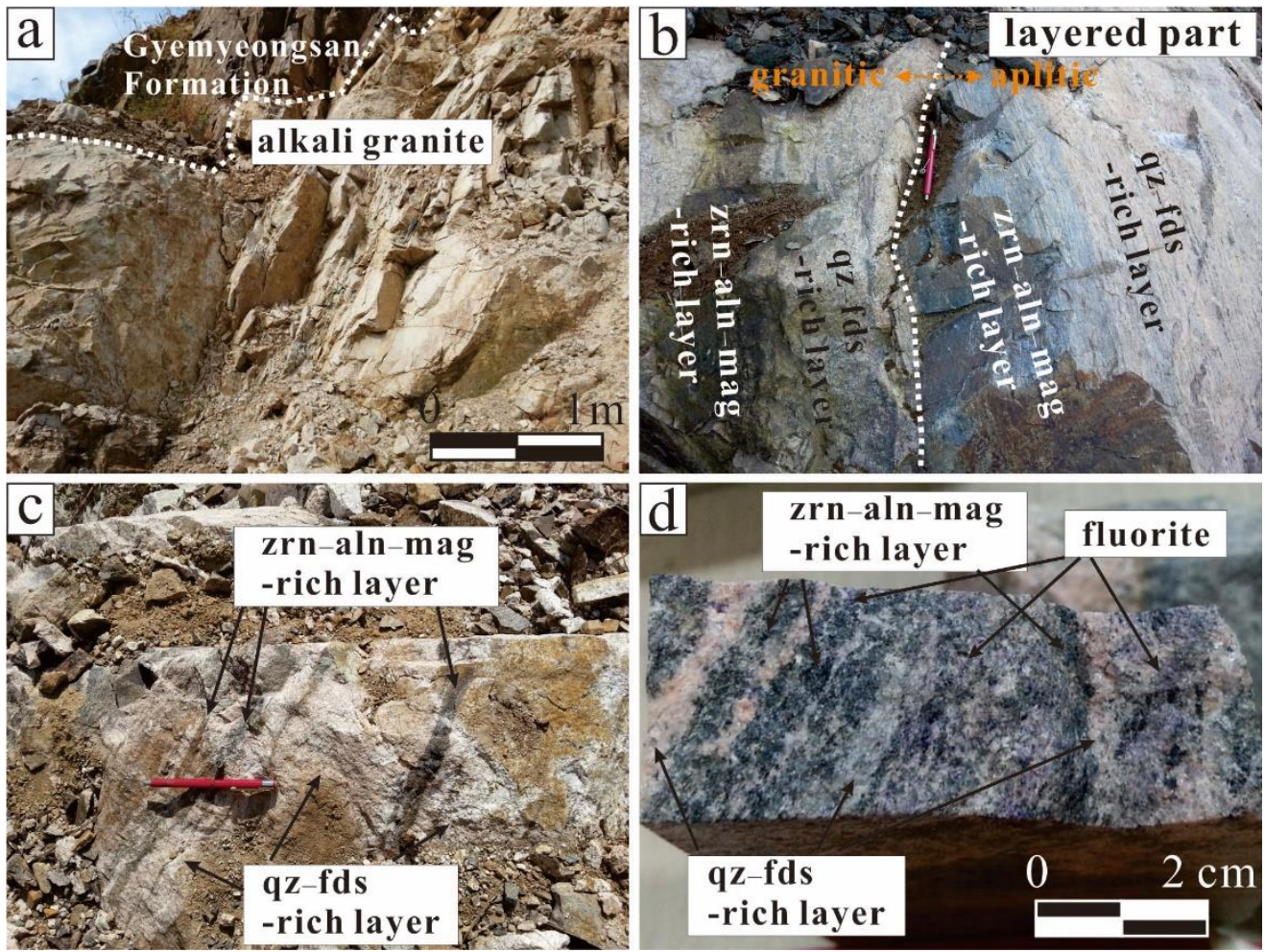

Figure 2. Layered alkali rocks. (a) The alkali granite intruded into the Gyemyeongsan Formation. (b) The quartz-feldspar (qz-fds)-rich layer and zircon-allanite-magnetite (zrn-aln-mag)-rich layer of the layered granite have a gradational relationship with the layered aplite. Pencil magnet: 12.5 $\mathrm{cm}$. (c) Discontinuous and fragmented quartz-feldspar-rich and zircon-allanite-magnetite-rich layers. Pencil magnet: $12.5 \mathrm{~cm}$. (d) Fluorite-rich (more than 1\%) aggregate occur in the layered granite. 


\section{Methods}

Multi-Collector Laser Ablation (LA)-ICP-MS

Zircons collected for $\mathrm{U}-\mathrm{Pb}$ isotopic analyses were mounted as rock chips in epoxy resin. We analyzed the zircons with a Nu Plasma II Multi-collector ICP-MS coupled to a New Wave Research $193 \mathrm{~nm}$ ArF excimer Laser Ablation system at the Korea Basic Science Institute, Ochang (Cheongju, Korea). This technique is very similar to that published by Paton et al. [17]. Samples were ablated in helium (He) gas (with a flow rate of $970 \mathrm{~mL} / \mathrm{min}$ ). Prior to entering the plasma, the He aerosol was mixed with $\mathrm{Ar}$ (flow rate $=600 \mathrm{~mL} / \mathrm{min}$ ). All analyses were completed in static ablation mode under normal conditions, including a beam diameter of 7 to $15 \mu \mathrm{m}$, a pulse frequency of $5 \mathrm{~Hz}$, and a beam energy density of $2.81 \mathrm{~J} / \mathrm{cm}^{2}$. A single U-Pb measurement included $30 \mathrm{~s}$ of on-mass background measurement, followed by $30 \mathrm{~s}$ of ablation with a stationary beam. The masses of 202, 204, 206, 207, and 208 were measured in secondary electron multipliers, and masses 232 and 238 were measured in an extra-high-mass Faraday collector. ${ }^{235} \mathrm{U}$ was calculated from the signal measured at mass 238, with the ${ }^{238} \mathrm{U} /{ }^{235} \mathrm{U}=137.88$. Mass 204 was used to monitor common ${ }^{204} \mathrm{~Pb}$ after discarding the ${ }^{204} \mathrm{Hg}$ background. In ICP-MS analyses, ${ }^{204} \mathrm{Hg}$ mainly originates from the He supply. The background counting rate on mass 204 was calculated on the basis of ${ }^{202} \mathrm{Hg}$. Age-related common lead correction [18] was used when the analysis revealed common lead contents above the detection limit. Two calibration standards were run in duplicate at the beginning and end of each analytical session, as well as at regular intervals during each session. Raw data were corrected for background, laser-induced elemental fractionation, mass discrimination, and drift in ion counter gains; they were then reduced to $\mathrm{U}-\mathrm{Pb}$ isotope ratios by their calibration to concordant reference zircons of known ages, with protocols adapted from Andersen et al. [19]. The standard zircons (1065 Ma; [20]) and Plešovice (337 Ma; [21]) were used for this calibration. Data processing and age calculations were performed off-line with the Iolite 2.5 [17] and Isoplot 3.71 [22] software programs. To minimize the effects of laser-induced elemental fractionation, the depth-to-diameter ratio of the ablation pit was kept low, and isotopically homogeneous segments of time-resolved traces were calibrated against the corresponding time interval for each mass in the reference zircon. To compensate for drift in instrument sensitivity and Faraday versus electron multiplier gain within an analytical session, a correlation of signal versus time was assumed for the reference zircons. All ages were calculated with $2 \sigma$ errors and without decay constant errors. Datapoint error ellipses in all figures are presented at the $2 \sigma$ level.

\section{Results}

\subsection{Alkali Granites and $\mathrm{Zr}-\mathrm{Nb}-\mathrm{Y}-\mathrm{REE}$ Mineralization}

The Paleozoic alkali granites occur as small-scale stocks and dikes (Figure 1) that are closely associated with iron and $\mathrm{Zr}-\mathrm{Nb}-\mathrm{Y}-\mathrm{REE}$ mineralization in the Gyemyeongsan Formation [1]. The alkali rocks that contain the $\mathrm{Zr}-\mathrm{Nb}-\mathrm{Y}-\mathrm{REE}$ mineralization are 50-100 m thick and approximately $1.2 \mathrm{~km}$ long, and they have a NE-SW-trending strike (Figure 1; [1]). Distinguishable parts that are especially enriched in $\mathrm{Zr}, \mathrm{Nb}, \mathrm{Y}$, and REE (i.e., zircon-allanite-magnetite-rich parts) have developed in the alkali rocks (Figures 2 and 3). These parts are separated into six bodies by a N-S-trending fault (Figure 1; [1]). In some parts of the alkali rocks (granite and aplite), fine- to medium-grained, layered textures are observed (Figures 2 and 3). 


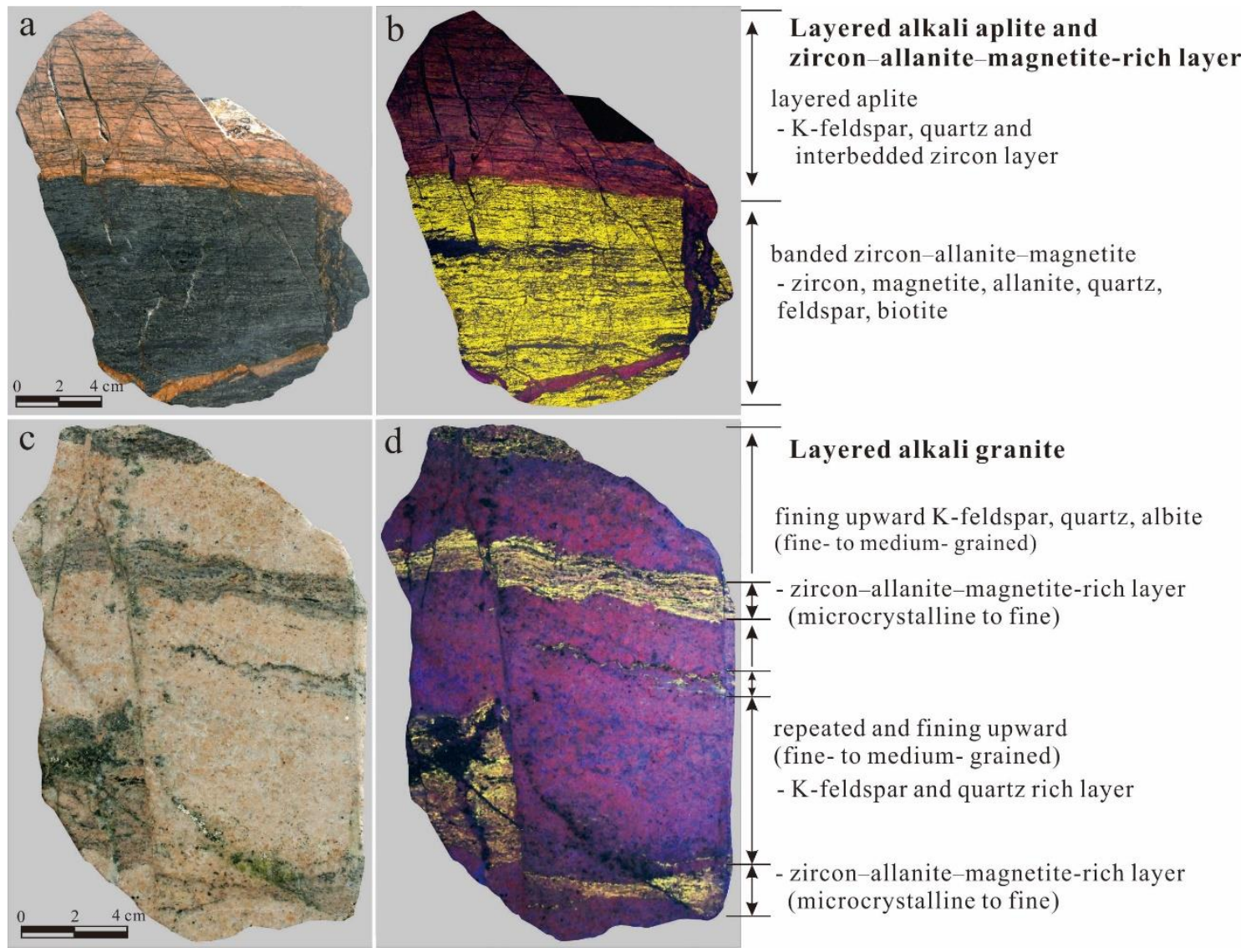

Figure 3. Representative $\mathrm{Zr}-\mathrm{Nb}-\mathrm{Y}$-rare earth element (REE)-enriched alkali rocks from the Chungju deposit. (a) Sharp contact between a zircon-allanite-magnetite-rich layer and layered alkali aplite. (b) Sample in (a) under UV illumination. The yellow emission is attributed to uranium activation [23]. (c) Layered alkali granite showing repeated grain-size grading in quartz-feldspar-rich layers and zircon-allanite-magnetite-rich layers. (d) Sample in (c) under UV illumination. Under UV radiation $(254 \mathrm{~nm})$, zircon shows a distinctive yellow fluorescence color.

\subsection{Layered Alkali Granite}

Layered alkali granite was observed in the study area. The layered alkali granite (Figures 2 and 3) could be divided into two parts on the basis of mineral assemblage and texture (i.e., zircon-allanite-magnetite-rich layers and quartz-feldspar-rich layers). The layers were discontinuous and varied in thickness from $1 \mathrm{~cm}$ to $50 \mathrm{~cm}$ (Figures 2 and 3).

\subsubsection{Quartz-Feldspar-Rich Layer}

The quartz-feldspar-rich layers exhibited repeated grain-size grading, in which K-feldspar (mostly microcline), quartz, and rare albite (Figures 3 and 4 ) comprised a fine- to medium-grained fining upward texture (Figure 3). Isolated microcrystalline zircon was distributed within the quartz, orthoclase, and microcline as inclusions (Figure 4a). The quartz-feldspar-rich layers exhibited equilibrium igneous textures such as euhedral and subhedral crystals with sharp boundaries (Figure 4a). In addition, graphic textures were observed in microscopic observations (middle of Figure 4a). The repeating quartz-feldspar-rich and zircon-allanite-magnetite-rich layers had sharp contacts (Figures 2 and 3). 

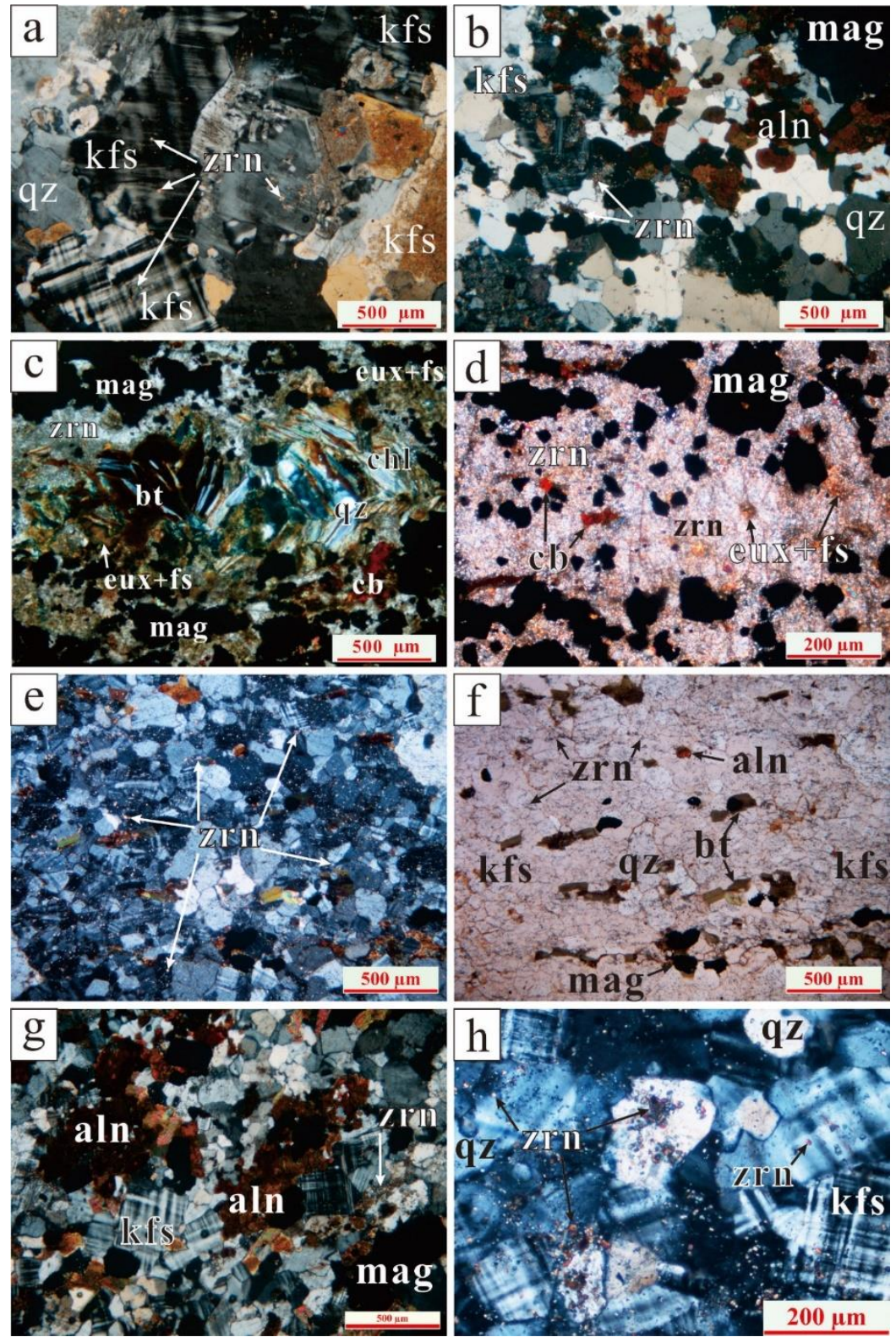

Figure 4. Representative $\mathrm{Zr}-\mathrm{Nb}-\mathrm{Y}-\mathrm{REE}$-enriched alkali rocks from the Chungju deposit. (a) Quartz-feldspar-rich layer from layered granite. Zircon occurred as an inclusion within quartz and K-feldspars, and a graphic texture was observed. (b) Zircon-allanite-magnetite-rich layer from layered granite. Zircon, allanite, and magnetite were co-precipitated along with quartz and K-feldspar. $(\mathbf{c}, \mathbf{d})$ Paragenetic association of zircon in a zircon-allanite-magnetite-rich layer. The white-colored regions were mostly composed of zircon aggregates. Note that magnetite grains exhibited various sizes and habits. (e,f) Shape preferred orientation of biotite grains, and ubiquitous zircon in layered aplite. (g) Alkali aplite comprising allanite aggregates, K-feldspar, magnetite of variable grain size, and microcrystalline zircon. (h) Zircon was ubiquitous as inclusions in quartz and K-feldspar grains (poikilitic texture) in alkali aplite. Abbreviations: qz (quartz), kfs (K-feldspar), mag (magnetite), aln (allanite), zrn (zircon), bt (biotite), chl (chlorite), eux (euxenite), fs (fergusonite), cb (columbite).

\subsubsection{Zircon-Allanite-Magnetite-Rich Layer}

Highly concentrated zones of zircon, allanite, and magnetite formed layers in the alkali granite (Figures 2, 3 and 5). These parts mainly comprised aggregates of microcrystalline zircon and magnetite, allanite, biotite, quartz, K-feldspar, and minor chlorite after biotite (Figure 4). The contents of quartz 
and K-feldspar were partially variable in the layer. In this layer, some REE minerals such as allanite, fergusonite, columbite, and euxenite (which have not yet been named with an official nomenclature) were observed (Figures 5 and 6). The magnetite present varied in grain size (from $1 \mu \mathrm{m}$ to $1 \mathrm{~mm}$ ) and form (Figure 4c,d and Figure $6 \mathrm{a}-\mathrm{d}$ ). Isolated grains reached up to approximately $1 \mu \mathrm{m}$ in size, and aggregates varied in size up to $1 \mathrm{~mm}$. Elongated aggregates of euhedral magnetite grains were observed, and anhedral coarse grains exhibited coalesced textures (Figure $4 \mathrm{c}, \mathrm{d}$ and Figure $6 \mathrm{a}-\mathrm{d}$ ). These observations suggest that magnetite grains aggregated and coalesced during the solidification of the melt.
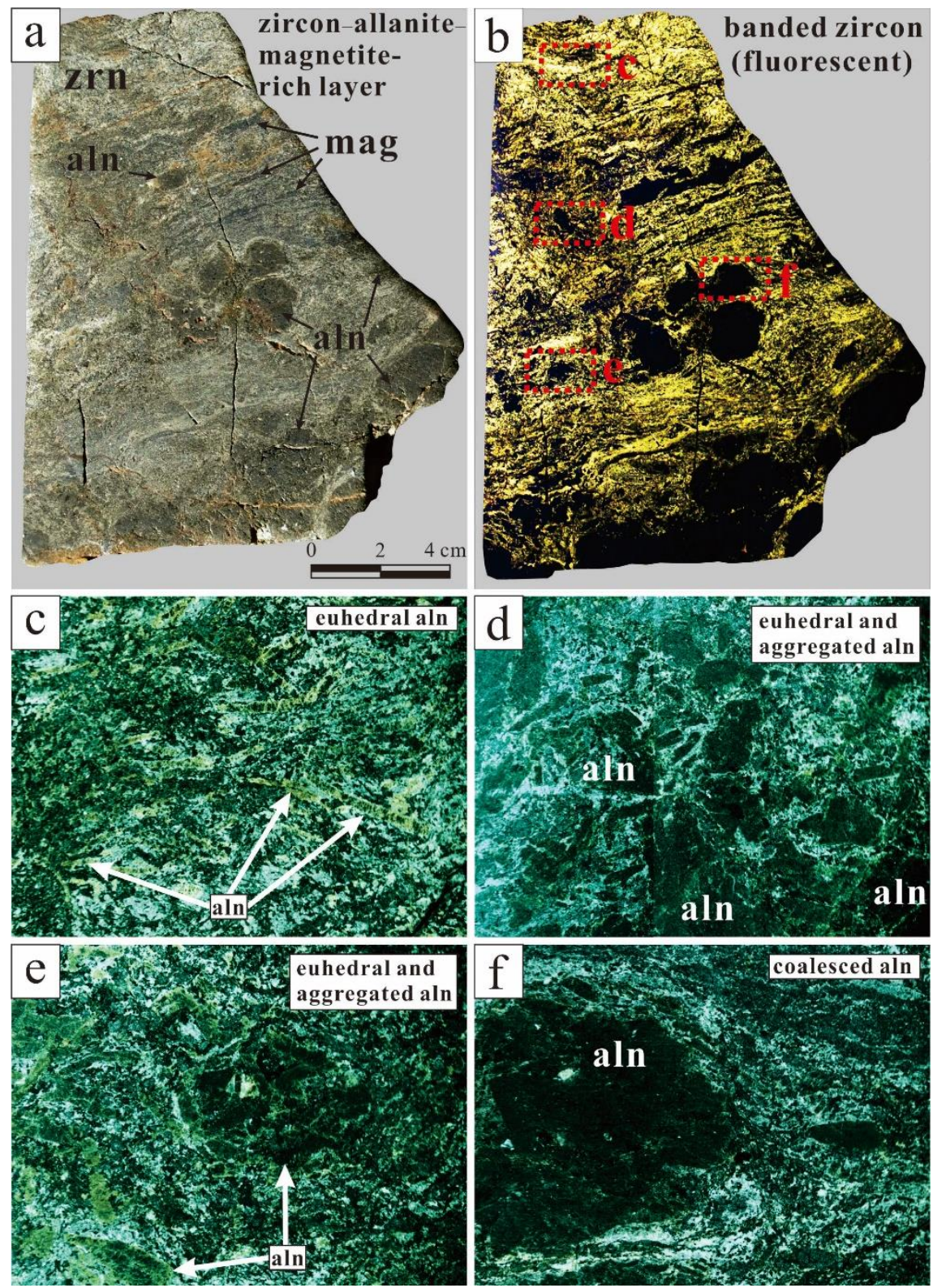

Figure 5. Photographs of part of an allanite-rich, zircon-allanite-magnetite-rich layer. (a) Zircon-allanite-magnetite-rich layer, which mostly consisted of zircon, magnetite, and various shaped allanite. (b) The zircon showed a distinctive yellow fluorescence color. (c) Euhedral laths of allanite. (d,e) Euhedral and aggregated allanite. (f) Coalesced allanite. Note the systematic change of texture of allanite grains from top to bottom in the sample. 

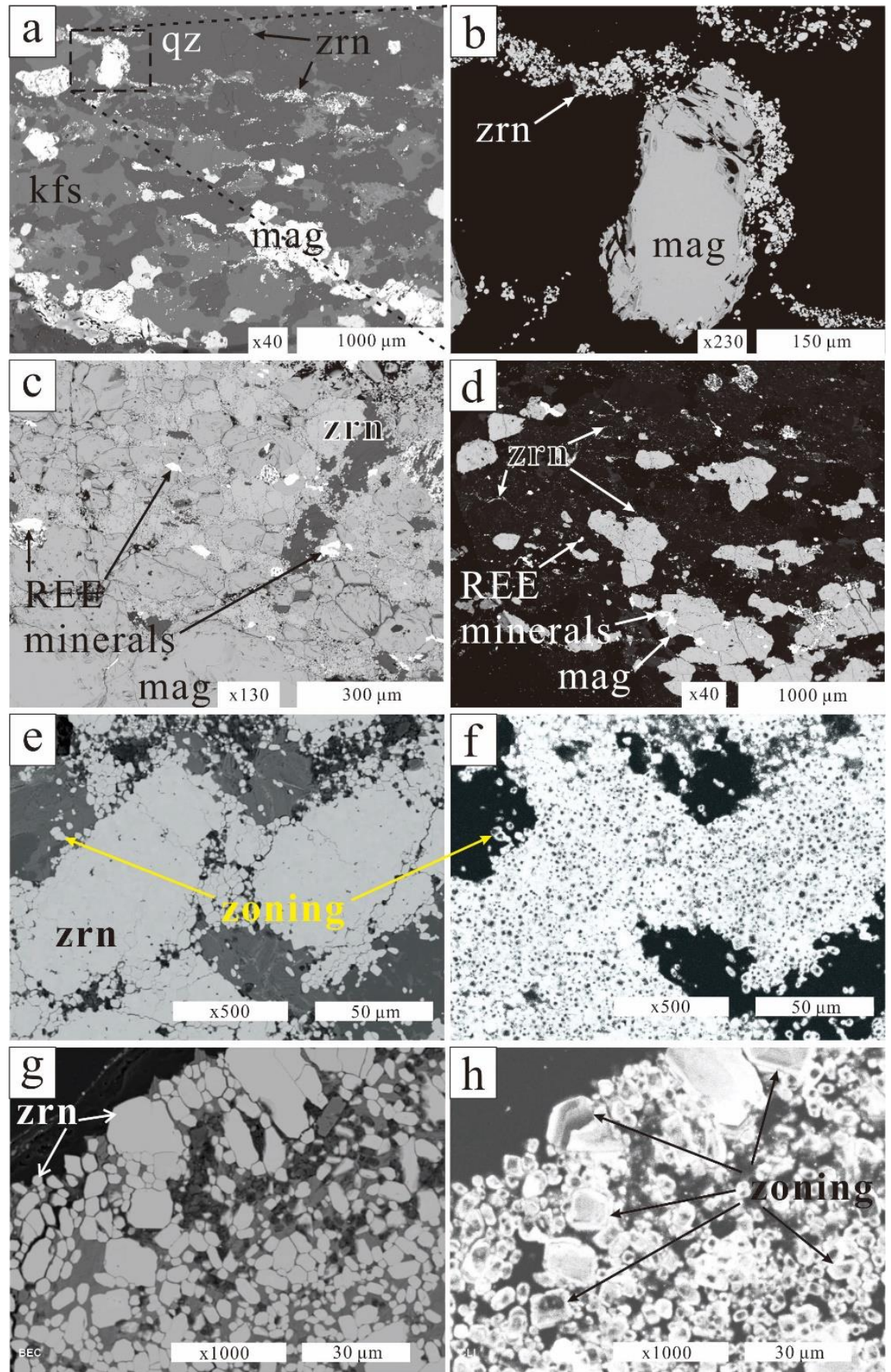

Figure 6. Photomicrographs of zircon aggregate from zircon-allanite-magnetite-rich layers in layered granite and layered aplite. (a,b) Back-scattered electron (BSE) images of the zircon-allanite-magnetite layer from layered granite. Note that aggregates of zircon showed crystal settling textures upon magnetite, quartz, and K-feldspar grains. (c) BSE image of a zircon-allanite-magnetite-rich layer in layered granite. (d) BSE image of alkali aplite showing a linear distribution of zircon grains. (e) BSE image of zircon aggregates in a zircon-allanite-magnetite-rich layer. (f) Cathodoluminescence (CL) image of same area as in (e), showing euhedral microcrystalline zircon aggregates. Note that zircons showed very fine (several micrometers) oscillatory zoning. (g) BSE image of zircon aggregates in a zircon-allanite-magnetite-rich layer. (h) Cathodoluminescence (CL) image of same area as in (g), showing euhedral microcrystalline zircon aggregates. Again, zircons showed very fine (several micrometers) oscillatory zoning. 
The allanite-rich parts of the zircon-allanite-magnetite-rich layers mainly consist of allanite, zircon, and magnetite (Figure 5). In these parts, allanite showed various shapes and sizes, such as lath-shaped euhedral allanite grains (1-6 mm in size; c axis), aggregated allanite (up to $1 \mathrm{~cm}$ ), and coalesced allanite (up to $2 \mathrm{~cm}$ ). Microcrystalline zircon grains filled the space between aggregated allanite (Figure $5 \mathrm{c}-\mathrm{e}$ ). These observations suggest that the allanite grains also aggregated and coalesced during the fractional crystallization and solidification of melt.

The microcrystalline zircon grains that comprised the aggregates in zircon-allanite-magnetite-rich layers exhibited fine (up to $2 \mu \mathrm{m}$ ) oscillatory zoning (Figure 6e-h) in cathodoluminescence (CL) and back-scattered electron (BSE) images. In BSE images, microcrystalline zircon displayed crystal settling textures upon magnetite, quartz, and K-feldspar grains (Figure 6a,b).

\subsection{Layered Alkali Aplite}

The linear texture in the layered aplite could be recognized by the distinctive yellow fluorescence color of zircon under ultraviolet (UV) illumination (Figure 3a,b). The layered aplite was mainly composed of fine-grained K-feldspar (major microcline and minor orthoclase), quartz, biotite, magnetite, microcrystalline zircon, and REE minerals (Figure 4e-h). Zircon grains were ubiquitously dispersed within the sample, and magnetite aggregates observed (Figures $4 \mathrm{e}-\mathrm{h}$ and $6 \mathrm{~d}$ ). Zircon grains also occurred as aggregates in the rock matrix and as inclusions in quartz and feldspar grains (Figure 4h). Linear aggregates of microcrystalline zircon and biotite grains that are parallel to zircon-allanite-magnetite-rich layers were also present (Figure $3 a, b$ and Figure 4e,f).

\subsection{Geochronology}

Constraining the age of the $\mathrm{Zr}-\mathrm{Nb}-\mathrm{Y}-\mathrm{REE}$ mineralization at Chungju is important for understanding the genesis of the deposit. In previous studies, the zircon ages were not obtained because the grain size was too small to analyze. In this study, we analyzed $\mathrm{U}-\mathrm{Th}-\mathrm{Pb}$ isotope systematics (Table 1) in zircon from the zircon-allanite-magnetite-rich layers and the alkali aplite (Figures 3 and 6) with a laser ablation multi-collector inductively coupled plasma mass spectrometry (LA-MC-ICP-MS). The analysis of cathodoluminescence images (Figure 6f,h) revealed that the zircons from the zircon-allanite-magnetite-rich layers comprised aggregated euhedral microcrystalline grains with micron-sized oscillatory zoning (up to several micrometers in size). The ${ }^{206} \mathrm{~Pb} /{ }^{238} \mathrm{U}$ ages obtained from zircon from the zircon-allanite-magnetite-rich layer and the alkali aplite were $331.1 \pm 1.5 \mathrm{Ma}$ and $334.5 \pm 8.9 \mathrm{Ma}$, respectively (Figure 7). Especially, the zircons from the zircon-allanite-magnetite-rich layers recorded a narrow range of $\mathrm{Th} / \mathrm{U}$ ratios $(0.69$ to 0.75$)$.

Table 1. Laser ablation multi-collector inductively coupled plasma mass spectrometry (LA-MC-ICP-MS)

$\mathrm{U}-\mathrm{Pb}-\mathrm{Th}$ isotopic analytical data for zircon from zircon-allanite-magnetite-rich layers and alkali aplite.

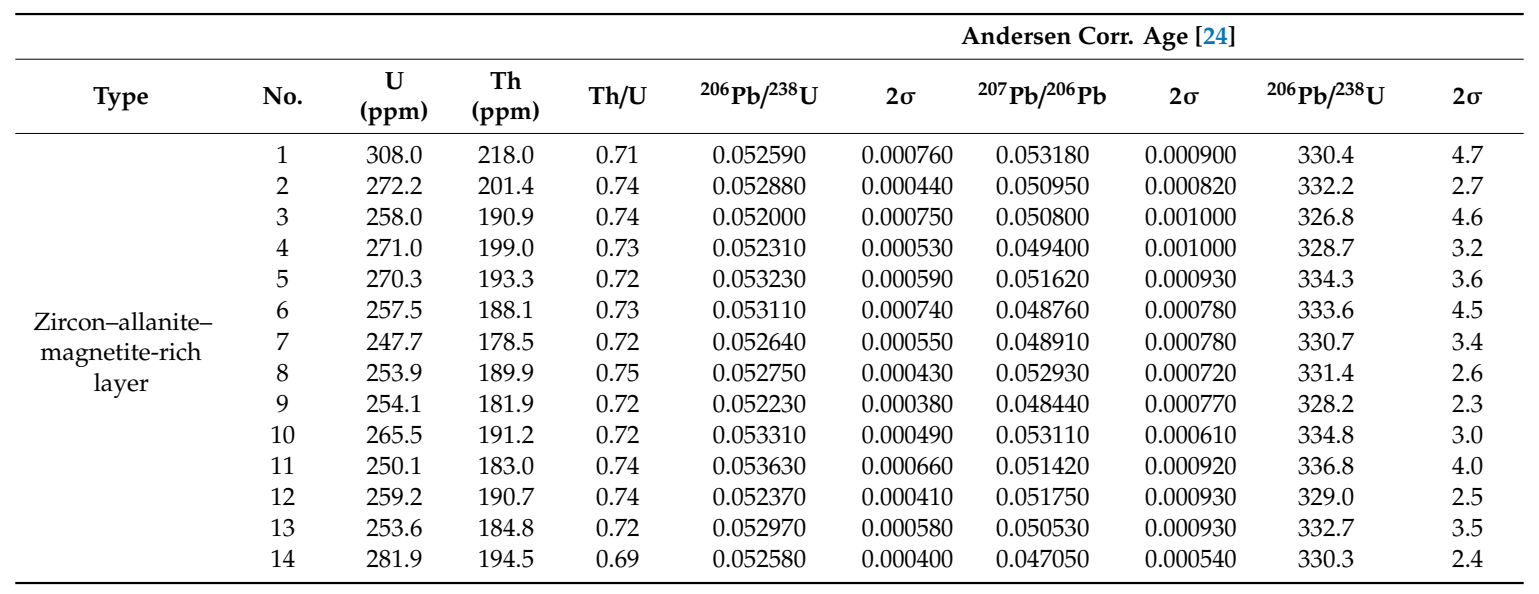


Table 1. Cont.

\begin{tabular}{|c|c|c|c|c|c|c|c|c|c|c|}
\hline \multirow[b]{2}{*}{ Type } & \multirow[b]{2}{*}{ No. } & \multirow[b]{2}{*}{$\underset{(\mathrm{ppm})}{\mathrm{U}}$} & \multirow[b]{2}{*}{$\begin{array}{c}\text { Th } \\
\text { (ppm) }\end{array}$} & \multirow[b]{2}{*}{$\mathrm{Th} / \mathrm{U}$} & \multicolumn{6}{|c|}{ Andersen Corr. Age [24] } \\
\hline & & & & & ${ }^{206} \mathrm{~Pb} /{ }^{238} \mathrm{U}$ & $2 \sigma$ & ${ }^{207} \mathrm{~Pb} /{ }^{206} \mathrm{~Pb}$ & $2 \sigma$ & ${ }^{206} \mathrm{~Pb} /{ }^{238} \mathrm{U}$ & $2 \sigma$ \\
\hline \multirow{7}{*}{ Alkali aplite } & 2 & 112.0 & 67.0 & 0.45 & 0.050600 & 0.003800 & 0.048900 & 0.001300 & 318.0 & 24.0 \\
\hline & 3 & 178.0 & 75.4 & 0.41 & 0.050000 & 0.002000 & 0.049600 & 0.002100 & 315.0 & 13.0 \\
\hline & 4 & 150.8 & 89.9 & 0.59 & 0.051900 & 0.002300 & 0.048000 & 0.002500 & 326.0 & 14.0 \\
\hline & 7 & 145.0 & 108.0 & 0.71 & 0.051200 & 0.001800 & 0.046970 & 0.000660 & 322.0 & 11.0 \\
\hline & 8 & 189.0 & 131.0 & 0.68 & 0.054800 & 0.001500 & 0.048900 & 0.002400 & 344.0 & 9.0 \\
\hline & 9 & 240.7 & 120.5 & 0.51 & 0.052800 & 0.003600 & 0.046076 & 0.000005 & 332.0 & 22.0 \\
\hline & 10 & 198.0 & 136.0 & 0.68 & 0.055900 & 0.001300 & 0.046082 & 0.000012 & 351.0 & 8.0 \\
\hline
\end{tabular}
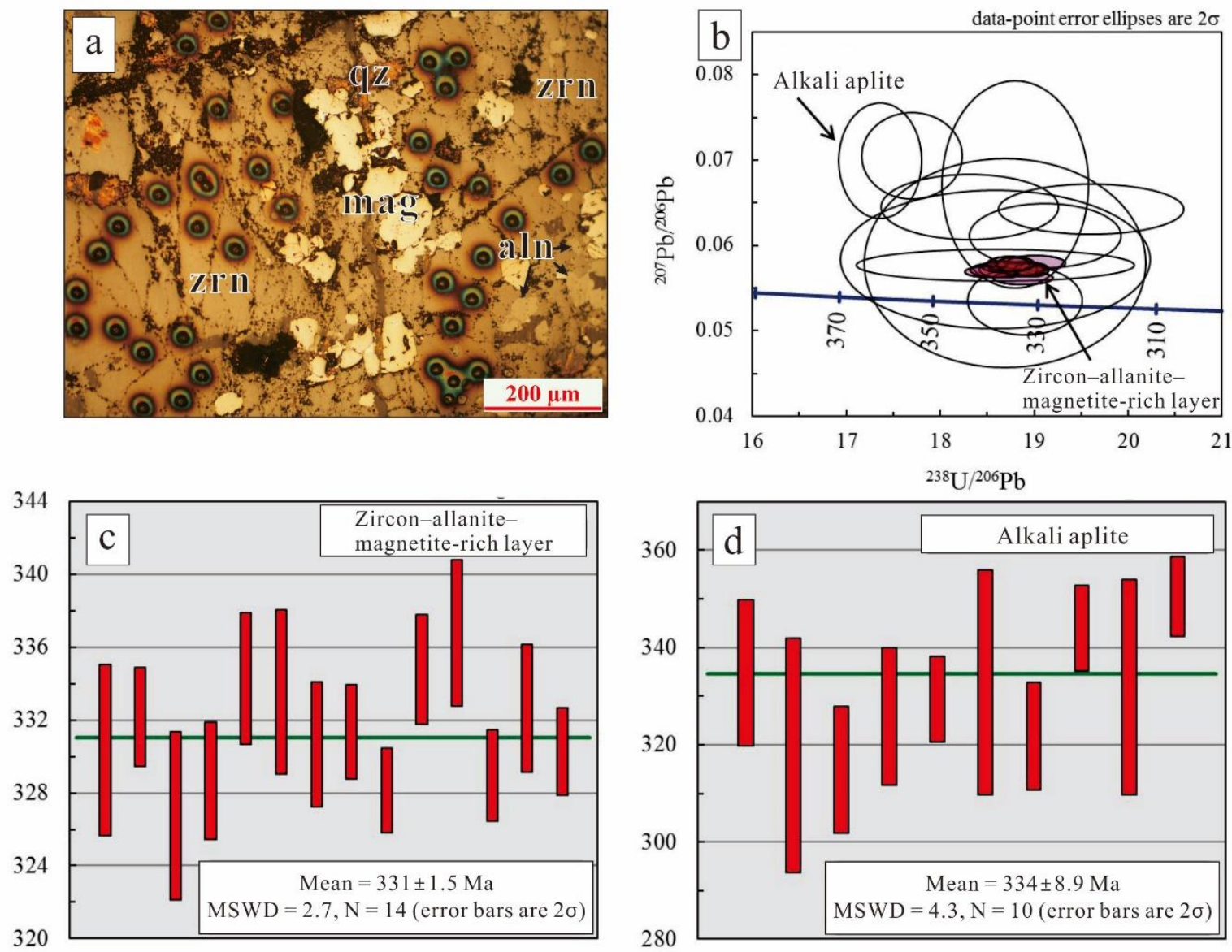

Figure 7. U-Pb isotope analyses. (a) Photomicrograph of zircon from a zircon-allanite-magnetite-rich layer. (b) Tera-Wasserburg Concordia diagram. The open circles mark alkali aplite, and the red ellipses mark zircon-allanite-magnetite-rich layers. (c) Weighted average zircon U-Pb ages of the zircon-allanite-magnetite-rich layers. (d) Ages of the alkali aplite from the Chungju deposit.

\section{Discussion and Conclusions}

In this study, the microcrystalline zircons from the zircon-allanite-magnetite-rich layers exhibited oscillatory zoning and aggregated textures up to several hundred micrometers in scale, and magnetite crystals exhibited various sizes and textures, appearing as isolated, aggregated, and coalesced grains (Figures 4 and 6). In addition, the settling textures of zircon onto magnetite, quartz, and feldspar grains were observed in BSE images (Figure 6). Furthermore, in an allanite-rich region (Figure 5), lath-shaped euhedral allanite, aggregated allanite, and coalesced allanite grains were systematically observed within zircon-allanite-magnetite-rich layers. Layered textures have been reported in highly fractionated 
granites with low viscosity [25-30]. The observation that the grain size becomes finer at the top of the layer and the alternating textures of the quartz-feldspar-rich and zircon-allanite-magnetite-rich layers of the layered granite can most reasonably be explained by the process of gravitational accumulation during a late magmatic stage [31-33].

Zirconium and other incompatible elements such as $\mathrm{REE}, \mathrm{Nb}, \mathrm{Y}$, Th, and $\mathrm{U}$ can be highly mobile in alkali- and fluorine-rich granitic systems [34-39] and can be concentrated in evolved granitic and pegmatitic melts by fractional crystallization [40-42]. The occurrence of more than $1 \%$ fluorite, various REE minerals, and high contents of K-feldspars in the Chungju alkali rocks match well with the results of these studies.

The ${ }^{238} \mathrm{U} /{ }^{206} \mathrm{~Pb}$ ages of the zircon from the zircon-allanite-magnetite-rich layers and the alkali aplite were $331.1 \pm 1.5 \mathrm{Ma}$ and $334.5 \pm 8.9 \mathrm{Ma}$, respectively. These ages were within the error of the previously reported Sm-Nd ages of the REE mineralization (330 $\pm 20 \mathrm{Ma}$; [1]) and the alkali granite $(331 \pm 20 \mathrm{Ma}$; [2]). This indicates that these ages are reliable and that Carboniferous alkali granite is related with $\mathrm{Zr}-\mathrm{Nb}-\mathrm{Y}-\mathrm{REE}$ mineralization in the Chungju area. The restricted range and high values of their $\mathrm{Th} / \mathrm{U}$ ratios $(0.69-0.75)$ of zircon from zircon-allanite-magnetite-rich layers indicate that zircons were formed during one magmatic event [43] and were not affected by epigenetic activities.

In conclusion, the layered part in the alkali granite found in the Chungju area, which contains layers with especially high contents of zircon, allanite, and REE minerals, was formed during the fractional crystallization of alkali magmas during the Carboniferous period. Further, evolved fluid which formed during alkali magma fractional crystallization caused the $\mathrm{Zr}-\mathrm{Nb}$-Y-REE mineralization in the Gyemyeongsan Formation [1,2]. Subsequently, it is assumed that $\mathrm{Zr}$ and REE were redistributed in the Gyemyeongsan Formation in two metamorphic events (Permian to Triassic, ca. 300-220 Ma; and Early Jurassic, 199-183 Ma; [9]). This study revealed that the $\mathrm{Zr}-\mathrm{Nb}-\mathrm{Y}-\mathrm{REE}$ mineralization was associated with alkali magmatism in the Chungju unit. The correlation between alkaline granite and REE mineralization found in this study could be used as a tool for REE exploration in other regions where an alkaline granite is intruded by a permeable geologic unit.

Author Contributions: S.G.N. designed and initiated the research. S.G.N. and M.E.P. were responsible for mineralogical, petrologic, and geochemical analyses. S.G.N. prepared the manuscript.

Funding: This research was supported by the Basic Research Project of the Korea Institute of Geoscience and Mineral Resources (KIGAM; Project No. 19-3211-1) funded by the Ministry of Science and ICT.

Acknowledgments: We are grateful to anonymous Minerals Journal reviewers for their detailed and constructive comments, which led to substantial improvements of the manuscript.

Conflicts of Interest: The authors declare no competing interest.

\section{References}

1. Park, M.E.; Kim, G.S. Genesis of the REE ore deposits, Chungju District, Korea: Occurrence features and geochemical characteristics. Econ. Environ. Geol. 1995, 28, 599-612, (In Korean, with English abstract).

2. Park, M.E.; Kim, G.S. Zircon deposit and rare earth element enriched metasomatic alkaline rocks at Kyemyeongsan Formation, Chungju, Korea: Paleozoic magmatism and Zr-REE-Nb mineralization. Geosci. Res. NE Asia 1999, 2, 61-73.

3. Oh, M.S. Allanite mineralization in the Mt. Eorae area. Econ. Environ. Geol. 1989, 22, 151-166, (In Korean, with English abstract).

4. Kim, J.S.; Park, M.E.; Kim, G.S. A geochemical study of the alkali granite in the Kyeomyeongsan Formation. Econ. Environ. Geol. 1998, 31, 349-360, (In Korean, with English abstract).

5. Park, M.E.; Kim, G.S.; Choi, I.S. Geochemical characteristics of allanite from rare metal deposits in the Chungju area, Chungcheongbuk-Do (Province), Korea. Econ. Environ. Geol. 1996, 29, 544-559, (In Korean, with English abstract).

6. Park, M.E.; Kim, G.S.; Choi, I.S. Geochemical and petrographical studies on the fergusonite associated with the $\mathrm{Nb}-\mathrm{Y}$ mineralization related to the alkaline granite, Kyemyeongsan Formation, Korea. Econ. Environ. Geol. 1997, 30, 395-406, (In Korean, with English abstract). 
7. Park, M.E.; Kim, G.S. Geochemistry of uranium and thorium deposits from the Kyemyeongsan pegmatite. Econ. Environ. Geol. 1998, 31, 365-374, (In Korean, with English abstract).

8. You, B.W.; Lee, G.J.; Koh, S.M. Mineralogy and Mineral-chemistry of REE minerals Occurring at Mountain Eorae, Chungju. Econ. Environ. Geol. 2012, 45, 643-659, (In Korean, with English abstract). [CrossRef]

9. Cheong, C.S.; Kim, N.; Yi, K.; Jo, H.J.; Jeong, Y.J.; Kim, Y.; Koh, S.M.; Iizuka, T. Recurrent rare earth element mineralization in the northwestern Okcheon Metamorphic Belt, Korea: SHRIMP U-Th-Pb geochronology, $\mathrm{Nd}$ isotope geochemistry, and tectonic implications. Ore Geol. Rev. 2015, 71, 99-115. [CrossRef]

10. Cho, M.; Kim, H. Metamorphic evolution of the Ogcheon metamorphic belt: Review and new age constraints. Int. Geol. Rev. 2005, 37, 41-57. [CrossRef]

11. Oh, C.W. A new concept on tectonic correlation between Korea, China and Japan: Histories from the late Proterozoic to Cretaceous. Gondwana Res. 2006, 9, 47-61. [CrossRef]

12. Lee, S.R.; Cho, M.; Cheong, C.-S.; Kim, H.; Wingate, M.T.D. Age, geochemistry, and tectonic significance of Neoproterozoic alkaline granitoids in the northwestern margin of the Gyeonggi massif, South Korea. Precambrian Res. 2003, 122, 297-310. [CrossRef]

13. Lee, K.S.; Chang, H.W.; Park, K.H. Neoproterozoic bimodal volcanism in the central Ogcheon belt, Korea: Age and tectonic implication. Precambrian Res. 1998, 89, 47-57. [CrossRef]

14. Cluzel, D.; Cadet, J.P.; Lapierre, H. Geodynamics of the Ogcheon belt (South Korea). Tectonophysics 1990, 183, 41-56. [CrossRef]

15. Cluzel, D.; Jolivet, L.; Cadet, J. Early Middle Paleozoic intraplate orogeny in the Ogcheon Belt (South Korea): A new insight on the Paleozoic buildup of East Asia. Tectonics 1991, 10, 1130-1151. [CrossRef]

16. Cluzel, D. Ordovician bimodial magmatism in the Okcheon belt (South Korea): An intracontinental rift-related volcanic activity. Southeast Asian Earth Sci. 1992, 7, 195-209. [CrossRef]

17. Paton, C.; Woodhead, J.D.; Hellstrom, J.C.; Hergt, J.M.; Greig, A.; Maas, R. Improved laser ablation U-Pb zircon geochronology through robust downhole fractionation correction. Geochem. Geophys. Geosystems 2010, 11, Q0AA06. [CrossRef]

18. Stacey, J.S.; Kramers, J.D. Approximation of terrestrial lead isotope evolution by a 2-stage model. Earth Planet. Sci. Lett. 1975, 26, 207-221. [CrossRef]

19. Andersen, T.; Griffin, W.L.; Jackson, S.E.; Knudsen, T.-L.; Pearson, N.J. Mid-Proterozoic magmatic arc evolution at the southwest margin of the Baltic Shield. Lithos 2004, 73, 289-318. [CrossRef]

20. Wiedenbeck, M.A.P.C.; Alle, P.; Corfu, F.; Griffin, W.L.; Meier, M.; Oberli, F.V.; Quadt, A.V.; Roddick, J.C.; Spiegel, W. Three natural zircon standards for U-Th-Pb, Lu-Hf, trace element and REE analyses. Geostand. Newsl. 1995, 19, 1-23. [CrossRef]

21. Sláma, J.; Košler, J.; Condon, D.J.; Crowley, J.L.; Gerdes, A.; Hanchar, J.M.; Horstwood, M.S.; Morris, G.A.; Nasdala, L.; Norberg, N.; et al. Plešovice zircon-A new natural reference material for $\mathrm{U}-\mathrm{Pb}$ and Hf isotopic microanalysis. Chem. Geol. 2008, 249, 1-35. [CrossRef]

22. Ludwig, K.R. Manual for Isoplot 3.7; special publication No. 4; Berkeley Geochronology Center: Berkeley, CA, USA, 2008.

23. Gleason, S. Ultraviolet Guide to Minerals; Vetter: Wiesloch, Germany, 1960.

24. Andersen, T. Correction of common lead in U-Pb analyses that to not report 204Pb. Chem. Geol. 2002, 192, 59-79. [CrossRef]

25. Manning, D.A.C. The effect of fluorine on liquidus phase relationships in the system Qz-Ab-Or with excess water at 1 kbar. Contrib. Mineral. Petrol. 1981, 76, 206-215. [CrossRef]

26. London, D. Internal differentiation of rare-element pegmatites: Effects of boron, phosphorus, and fluorine. Geochim. Cosmochim. Acta 1987, 51, 403-420. [CrossRef]

27. Rockhold, J.R.; Nabelek, P.I.; Glascock, M.D. Origin of rhythmic layering in the Calamity Peak satellite pluton of the Harney Peak Granite, South Dakota: The role of boron. Geochim. Cosmochim. Acta 1987, 51, 487-496. [CrossRef]

28. Sparks, R.S.J.; Huppert, H.E.; Koyaguchi, T.; Hallworth, M.A. Origin of modal and rhythmic igneous layering by sedimentation in a convecting magma chamber. Nature 1993, 361, 246-249. [CrossRef]

29. Zaraisky, G.P.; Seltmann, R.; Shatov, V.V.; Aksyuk, A.M.; Shapovalov Yu, B.; Chevychelov, V.Y. Petrography and geochemistry of Li-F granites and pegmatite-aplite banded rocks from the Orlovka and Etyka tantalum deposits in Eastern Transbaikalia, Russia. In Mineral Deposits: Research and Exploration. Where Do They Meet? Papunen, H., Ed.; Balkema: Rotterdam, The Netherlands, 1997; pp. 695-698. 
30. Fedkin, A.; Seltmann, R.; Bezmen, N.; Zaraisky, G. Experimental testing of line rocks in Li-F granites: Evidence from superliquidus experiments with $\mathrm{F}$ and $\mathrm{P}$ added. Bull. Czech Geol. Surv. 2002, 77, 113-125.

31. Smith, T. The sedimentation of particles having a dispersion of sizes. Trans. Inst. Chem. Eng. 1996, 44, 153-157.

32. Greenspan, H.P.; Ungarish, M. On hindered settling of particles of different sizes. Int. J. Multiph. Flow 1982, 8, 587-604. [CrossRef]

33. Simura, R.; Ozawa, K. Mechanism of crystal redistribution in a sheet-like magma body: Constraints from the Nosappumisaki and other shoshonite intrusions in the Nemuro Peninsula, Northern Japan. J. Petrol. 2006, 47, 1809-1851. [CrossRef]

34. Rubin, J.N.; Henry, C.D.; Price, J.G. The mobility of zirconium and other immobile elements during hydrothermal alteration. Chem. Geol. 1993, 110, 29-47. [CrossRef]

35. Aja, S.U.; Wood, S.A.; Williams-Jones, A.E. The aqueous geochemistry of Zr and the solubility of some Zr-bearing minerals. Appl. Geochem. 1995, 10, 603-620. [CrossRef]

36. Aja, S.U.; Wood, S.A.; Williams-Jones, A.E. The solubility of some alkali-bearing Zr minerals in hydrothermal solutions. MRS Online Proc. Libr. Arch. 1997, 423, 69-74. [CrossRef]

37. Bau, M.; Dulski, P. Comparative-study of yttrium and rare-earth element behavior in fluorine-rich hydrothermal fluids. Contrib. Mineral. Petrol. 1995, 119, 213-223. [CrossRef]

38. Veksler, I.V.; Dorfman, A.M.; Kamenetsky, M.; Dulski, P.; Dingwel, D.B. Partitioning of lanthanides and Y between immiscible silicate and fluoride melts, fluorite and cryolite and the origin of the lanthanide tetrad effect in igneous rocks. Geochim. Cosmochim. Acta 2005, 69, 2847-2860. [CrossRef]

39. Ayers, J.C.; Zhang, L.; Luo, Y.; Peters, T. Zircon solubility in alkaline aqueous fluids at upper crustal condition. Geochim. Cosmochim. Acta 2012, 96, 18-28. [CrossRef]

40. Jiang, S.Y.; Wang, R.C.; Xu, X.S.; Zhao, K.D. Mobility of high field strength elements (HFSE) in magmatic-, metamorphic-, and submarine-hydrothermal systems. Phys. Chem. Earth 2005, 30, 1020-1029. [CrossRef]

41. Salvi, S.; Williams-Jones, A.E. Alteration, HFSE mineralisation and hydrocarbon formation in peralkaline igneous systems: Insights from the Strange Lake Pluton, Canada. Lithos 2006, 91, 19-34. [CrossRef]

42. Van Lichtervelde, M.; Holtz, F.; Hanchar, J.M. Solubility of manganotantalite, zircon and hafnon in highly fluxed peralkaline to peraluminous pegmatitic melts. Contrib. Mineral. Petrol. 2010, 160, 17-32. [CrossRef]

43. Hoskin, P.W.O.; Schaltegger, U. The composition of zircon and igneous and metamorphic petrogenesis. Rev. Mineral. Geochem. 2003, 53, 27-62. [CrossRef] 